\title{
BUDAYA SPIRITUAL: PERSEPSI PEZIARAH PADA MAKAM KERAMAT LELULUR SUMEDANG
}

\author{
Oleh Tjetjep Rosmana \\ Balai Pelestarian Sejarah dan Nilai Tradisional Bandung \\ Jln. Cinambo No. 136 Ujungberung Bandung \\ Email: tjetjeprosmana@yahoo.co.id
}

\begin{abstract}
Abstrak
Sikap keramat dalam anggapan suatu masyarakat adalah tempat yang dikeramatkan karena tempat bersemayamnya arwah leluhur yang memiliki kekuatan gaib. Pada suatu waktu di tempat keramat dijadikan pusat kegiatan religius, yakni upacara persembahan kepada Tuhan Yang Maha Kuasa. Dalam situs religius ini, setiap tingkah laku manusia dikeramatkan yang diiringi suasana hati dan motivasi yang ditimbulkan oleh simbol-simbol sakral (keramat) dalam diri manusia.

Situasi demikian itu terbentuk dalam kesadaran spiritual sebuah masyarakat. Sesungguhnya setiap individu memiliki persepsi yang berbeda terhadap tempat yang dikeramatkan. Hal ini sesuai dengan kondisi dan kebutuhan masing-masing. Demikian pula terhadap makam keramat leluhur Sumedang yang kerap dikunjungi oleh banyak peziarah. Salah satunya makam keramat Pangeran Santri, Ratu Pucuk Umum, Pangeran Kornel, dan sebagainya.
\end{abstract}

Kata Kunci: Budaya spiritual, makam keramat, Sumedang.

\begin{abstract}
A sacred attitude on people live in a sacred place is the burial of an ancestors spirit and supernatural. Sometimes, it is made as a center of religiousness, for example a god worship through religious site. On this site everyones attitude is being sacred by feeling and motivation which showed sacred symbols self inside.

The situation formed in a spiritual awareness of society. Actually, everyone has different perception and motivtion about those places. Of course, it depends on each needs conditions. In such a case, the sacred burial of Sumedang often visited by visitors. Such as the sacred burial of Pangeran Santri, Ratu Pucuk Umum, Pangeran Kornel, etc.
\end{abstract}

Keywords: Spiritual culture, sacred burial, Sumedang.

\section{A. Pendahuluan}

Manusia pada dasarnya selalu ingin memenuhi semua kebutuhan hidupnya. Menurut bentuknya kebutuhan hidup manusia itu dapat dibagi menjadi dua jenis yaitu kebutuhan material dan kebutuhan spiritual. Kebutuhan material berupa sandang, pangan dan papan merupakan kebutuhan manusia untuk mempertahankan kehidupannya. Oleh 
karena itu, untuk memenuhi kebutuhan tersebut manusia berusaha semaksimal kemampuan pikirnya meskipun tidak selalu lancar. Hal ini dikarenakan keterbatasan akan kemampuan akal dan pengetahuan yang dimilikinya. Untuk mengimbangi keterbatasannya, adakalanya manusia melakukan sesuatu yang lebih bersifat spiritual. Melalui perilaku spiritual ini manusia berusaha memenuhi akan kebutuhan rohaninya. Kebutuhan rohani atau kebutuhan spiritual ini adalah kebutuhan nonmateri. Dengan pemenuhan kebutuhan spiritual ini manusia berupaya mendekatkan diri kepada Yang Maha Kuasa dalam rangka mencapai tujuan tertentu yang dikehendakinya, misalnya pendalaman iman.

Adakalanya pula melalui perilaku spiritual manusia melakukan upaya untuk memenuhi kebutuhan-kebutuhan hidupnya, termasuk kebutuhan materi. Perilaku spiritual dalam rangka upaya manusia untuk memenuhi kebutuhan hidup ini dilakukan manusia dengan sikap 'panembah' kepada Yang Maha Kuasa. Karena itu dalam sikap "panembah" ini manusia memasrahkan diri pada kekuatan Illahi.

Secara konseptual sikap "panembah" yang pasrah diri pada kekuatan Illahi itu merupakan wujud dari emosi keagamaan (religius emotion). Koentjaraningrat (1992) mengatakan bahwa emosi keagamaan itu adalah suatu getaran jiwa yang pada suatu ketika pernah menghinggapi seorang manusia dalam waktu hidupnya. Walaupun getaran itu hanya berlangsung beberapa waktu saja. Emosi keagamaan ini ada di belakang setiap kelakuan serba religi, sehingga menyebabkan timbulnya sikap keramat, baik pada kelakuan manusia itu sendiri, maupun pada tempat kelakuan itu diungkapkan.

Sikap keramat dalam anggapan di kalangan suatu masyarakat di tempat- tempat yang dikeramatkan merupakan tempat bersemayamnya arwah leluhur atau dewa-dewi dan kekuatan-kekuatan gaib yang pada suatu waktu di tempat tersebut dijadikan pusat kegiatan keagamaan, misalnya upacara persembahan kepada Tuhan Yang Maha Kuasa melalui situs religius. Dalam situs religius ini setiap tingkah laku manusia dikeramatkan diiringi suasana hati dan motivasi yang ditimbulkan oleh simbolsimbol sakral (keramat) dalam diri manusia. Situasi yang demikian itu terbentuk dalam kesadaran spiritual sebuah masyarakat (Clifford Geertz, 1992: 33).

Sehubungan dengan uraian di atas, sesungguhnya setiap individu memiliki persepsi yang berbeda terhadap tempattempat yang dikeramatkan tersebut. Perbedaan tersebut tentunya sesuai dengan kondisi dan kebutuhan masingmasing pula. Demikian pula terhadap makam keramat leluhur Sumedang yang dikemukakan hasil penelitian ini.

Tempat-tempat keramat adalah tempat bersemayamnya arwah leluhur atau dewa-dewi, juga kekuatan-kekuatan gaib yang ada pada benda tertentu, yang kebetulan tersimpan di tempat keramat itu. Dalam hal ini Frazer memberikan pengertian kekuatan gaib (magi) adalah kekuatan yang ada pada benda-benda dan terhadapnya manusia berusaha menguasainya untuk tujuan tertentu.

Di tempat keramat pada saat-saat tertentu dijadikan sebagai pusat kegiatan keagamaan, seperti upacara-upacara persembahan kepada "Yang Maha Kuasa" melalui situs religius. Dalam situs religius setiap tingkah laku manusia dikeramatkan dan disertai suasana hati dan motivasi yang ditimbulkan oleh simbol-simbol sakral (keramat) dalam diri manusia. Situasi yang demikian membentuk kesadaran spiritual sebuah 
masyarakat (Clifford Geertz, 1992: 33, dalam Tashadi, dkk:1994/1995)

Pada tempat keramat biasanya bersemayam tokoh leluhur yang semasa hidupnya memiliki karisma. Tokoh ini dimitoskan oleh pendukungnya dan dijadikan sebagai panutan perilaku kelompok orang. Mitos itu sendiri memberikan arah kepada kelakuan manusia. Lewat mitos ini manusia dapat turut serta mengambil bagian dalam kejadian-kejadian sekitarnya dan menangggapi daya-daya kekuatan alam (Van Peursen, 1992:37; J. Van Baal, (1987) mengartikan mitos adalah kebenaran religius dalam bentuk cerita yang menjadi dasar situs. Mitos ini merupakan bagian dari suatu kepercayaan yang hidup di antara sejumlah bangsa.

Tempat keramat yang didukung oleh keberadaan tokoh mitos kharismatis menjadi tempat ziarah bagi mereka dengan tujuan dan maksud tertentu. Ziarah ini pada hakekatnya menyadarkan kondisi manusia sebagai pengembara di dunia yang hanya mampir ngombe. Ziarah yang menuju tempat keramat seperti ke makam leluhur maksudnya sangat bervariasi dan salah satunya adalah untuk memperoleh restu leluhur yang dianggap telah lulus dalam ujian hidup (Subagya, 1981:141). Sehubungan hal tersebut, yang menjadi pokok permasalahan adalah:

1. Apa dan bagaimana persepsi masyarakat sekitar dan peziarah terhadap makam-makam keramat tersebut?

2. Nilai-nilai apa saja yang dapat dipetik dari ritual ini?

Tujuan penulisan antara lain untuk mengetahui gambaran tokoh-tokoh panutan masyarakat yang legendaris, dan kharismatik, serta untuk mengetahui eksisensi nilai luhur yang diajarkan oleh tokoh-tokoh tersebut kepada masyarakat pendukungnya. Selain itu untuk mengetahui persepsi dan motivasi masyarakat setempat dan peziarah lainya terhadap makam keramat tersebut.

Ruang lingkup penulisan Budaya Spriritual dibatasi pada persepsi peziarah pada makam Pangeran Santri, Ratu Pucuk Umum, dan Pangeran Kornel yang merupakan tempat keramat yang banyak dikunjungi peziarah yang berasal dari berbagai daerah. Kunjungan para peziarah ternyata setiap tahunnya meningkat walaupun masyarakat Indonesia khususnya berada dalam era teknologi canggih dan era globalisasi.

Metode penelitian dipilih melalui pendekatan secara kualitatif. Dengan pendekatan ini diharapkan dapat menjaring seluruh data sesuai dengan permasalahan. Oleh karena itu, dalam penelitian ini diperlukan informan yang terdiri dari masyarakat setempat, peziarah dari luar, dan generasi muda. Agar dapat memperoleh data yang diharapkan dan sesuai dengan permasalahan, maka teknik pengumpulan data yang dipergunakan adalah observasi, wawancara, dan studi pustaka.

\section{B. Hasil dan Bahasan}

\section{Persepsi pada Makam Keramat}

Terdapat beberapa pendapat tentang pengertian persepsi atau pandangan. Franz Magnis Suseno (1993) mengemukakan bahwa persepsi atau pandangan merupakan keseluruhan keyakinan manusia untuk memberi struktur yang bermakna kepada alam pengalamannya. Sementara itu, Clifford Geertz mengemukakan bahwa pandangan tentang dunia adalah gambaran tentang kenyataan apa adanya, konsep tentang alam, diri, dan masyarakat. Persepsi atau pandangan ini mengandung gagasan mengenai tatanan, Persepsi ini secara emosional dibuat dapat diterima dengan disajikan sebuah gambaran tentang masalah-masalah aktual dari cara hidup dan 
cara hidup ini adalah ekspresi otentik. Persepsi ini dibentuk oleh suatu cara berpikir yang dapat merasakan tentang nilai-nilai, organisasi sosial, kelakuan, peristiwa-peristiwa dan segi-segi lain dari pengalaman. Oleh karena, itu persepsi merupakan sebuah pengaturan mental dari pengalaman itu dan pada gilirannya mengembangkan suatu sikap terhadap hidup (Mulder, 1986: 30).

Persepsi atau pandangan dapat memunculkan makna pada "sesuatu". Makna ini dapat disimpan di dalam simbol-simbol yang keabsahannya diakui oleh para pendukungnya. Simbol-simbol religius yang disakralkan biasanya dimunculkan dalam peristiwa ritus dan waktu tertentu yang disakralkan pula. Simbol-simbol sakral tersimpan dalam wujud benda-benda tertentu yang dianggap mempunyai makna. Makna ini adalah sesuatu yang mempengaruhi semua hal, yang melampaui kekuasaan dan kekuatan manusia dan berada di luar jalur yang normal dan wajar (J. Van Baal, 1987).

Persepsi yang berkenaan dengan kehidupan religius itu kadang diperkuat dengan mitos. Mitos menjadi sesuatu kebenaran absolut yang tidak bisa diganggu gugat. Mitos menguatkan suatu misteri, mewujudkan peristiwa primordial yang masih selalau diceritakan dan diulang kembali pada waktu sekarang. Dalam hal ini mitos mengungkapkan struktur keilahian, yang mengatasi semua atribut dan mendamaikan semua pertentangan secara lebih mendalam daripada yang bisa diungkapkan oleh pengalaman rasional (Susanto, Hary: 1987).

\section{Persepsi Masyarakat Sekitar}

Masyarakat sekitar memiliki persepsi terhadap makam keramat di Komplek pemakaman Pasarean Gede Gunung Ciung. Menurut mereka makammakam keramat sering dijadikan tempat ziarah antara lain makam Pangeran Santri, Ratu Pucuk Umum, Pangeran Kornel, dsb.

Kata "ziarah" menurut kamus Bahasa Indonesia artinya kunjungan ketempat yang dianggap keramat.. Berziarah kubur artinya berkunjung ketempat yang dianggap keramat atau mulia, seperti ke makam untuk mengirim doa. Berziarah ke makam wali artinya berkunjung ke makam wali.

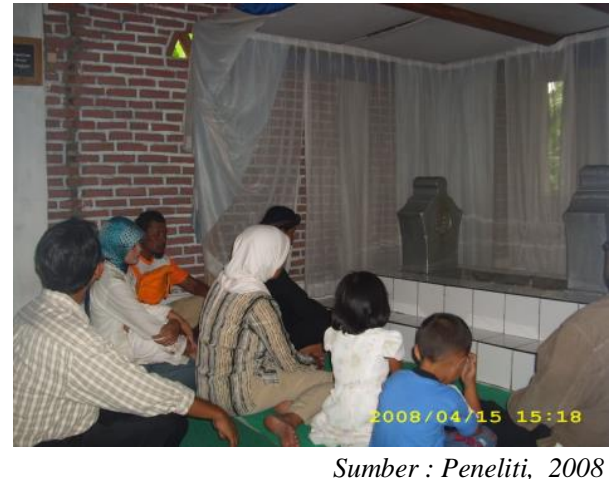

Berziarah ke makam Pangeran Kornel

Menurut aturan Islam, ziarah itu bukan hanya sekedar mengunjungi makam para wali atau syuhada; dan bukan pula sekedar ingin mengetahui akan tetapi ziarah makam itu untuk mendo,akan yang dimakamkan. Mengirim do,a, dan mengirim pahala untuknya atas bacaan-bacaan dari ayatayat Al-Qur'an dan kalimah-kalimah Thayyibah, seperti bacaan Tahlil, Tahmid, Tasbih, Shalawat, dan lain-lain. Apalagi kalau yang di ziarahi adalah makam seseorang yang dianggap seorang wali atau ulama, atau tokoh yang telah berjasa kepada masyarakat. Sebagai orang yang tahu berhutang budi, sepatutnya mendoakan dan menghadiahkan pahala serta bacaan-bacaan. Dengan demikian, ziarah menurut syariat Islam adalah termasuk amal shaleh, amal perbuatan yang baik. 
Nabi Muhammad Saw. pernah melakukan ziarah, sebagaimana yang diriwayatkan oleh Imam Muslim, Ahmad dan Ibnu Majah berikut ini :"Rosulallah Saw. ke makam para Syuhada Uhud dan ke makam ahli Baqi, maka ziarah hukumnya sunnah, artinya apabila dikerjakan akan mendapat pahala, dan apabila tidak dilakukan tidak apa-apa. Waktu berziarah ke makam tersebut Rosulallah Saw. memberi salam dan mendoakan kepada mereka, berucap: "semoga kesejahteraan tetap bagimu wahai ahli kubur dan orang-orang mu'min dan orang-orang Islam. Insyaallah kami akan bertemu dengan kami.kami mohon kesehatan kepada Allah SWT untuk kami dan kamu".

Sebuah hadist yang diriwayatkan oleh Imam Ibnu Majah dari Shahabat Ibnu Mas'ud, menyebutkan, Sesungguhnya Rasullah Saw. bersabda: "Aku dulu telah melarang kamu berziarah ke kubur, maka (sekarang berziarahlah. Karena ziarah kubur itu dapat ber-zuhud terhadap dunia dan dapat pula mengingatkan alam Akhirat".

Menurut syariat agama Islam, ziarah kubur itu bukan hanya sekedar mengujungi kubur, tetapi mendoakan kepada yang dikubur atau yang dimakamkan dan mengirim pahala kepadanya atad bacaan-bacaan dari ayat-ayat suci Al-Quran dan kalimah-kalimah Thayyibah, seperti bacaan Tahlil, Tahmid,Tasbih, Shalawat, dan lain-lain.

Salah seorang informan yang tinggal di sekitar komplek makam keramat, menyebutkan bahwa makammakam tersebut dikeramatkan dan sering diziarahi. Menurutnya, bila hendak berziarah atau bermalam di makam keramat ada aturan dan tatakrama tertentu. Adapun tatacara berziarah, antara lain sebelumnya hendaklah meminta izin terlebih dahulu kepada juru kunci, yaitu dengan mengungkapkan data diri (nama dan asal) kepada kuncen, menyatakan maksud dan tujuan kedatangan. Bila memasuki areal makam keramat terlebih dahulu harus "beberesih" berwudlu, dan berlaku sopan dan tertib, tidak gaduh. Selanjutnya, tawasulan atau tahlilan/berdoa sesuai ajaran agama (Islam) biasanya dipimpin kuncen. Apabila berdoanya tidak dipimpin kuncen, kuncen tetap mengawasi dan mengarahkan agar tidak menyimpang dari ajaran agama. Ketentuan tersebut yang dipegang teguh, baik oleh peziarah maupun masyarakat sekitar komplek makam keramat, antara lain tidak boleh berkata yang tidak sopan dan berlaku tertib. Apabila tiba di pintu gerbang makam memberi salam, dengan mengucapkan, "Assalaamu'alaikum ahladdiyari minal mu'minina wa innaa insyaa Allaahubikum laahiquun nas aluuaaha lanna walakumul aafiyata'. Atau dengan mengucapkan, "Assalaamu'alaikum daara qaumin mu'minin fainnnaa insyaa Allaahu bikum laahiquun, yang artinya: Kesejahteraan semoga Mu'min. Insya Allah kami akan bertemu dengan kamu. Sesampai di depan makam yang dituju, kemudian menghadap ke arah muka mayat (menghadap ke timur) seraya mengucapkan salam khusus, yaitu mengucapkan, “Assalamu'alaikum ya ...... (nama almarhum), atau membaca “Assalamu alaikum darokao mu'minunna antaum lana parotuwwa'ina bikum lahikum Allahumalatah rinaazrohum walatuhdilana badahum; dilanjutkan membaca Surat Alfatihah (1 kali). Selanjutnya membaca "Ilaahadirotin nabiyyil mustopa Muhamadin shollalohu'alaihi wa salam wa ala alihi wa azwaajihi wa aulaadihi wa dzuriyyatihi syaiullilahumul; dilanjutkan membaca Surat Alfatihah (1kali). Selanjutnya membaca, "Tsumailaahadirotin ikhwanihi minal ambiyaaiwal mursalina wal auliyaai wasyuhadaai washolihinna wa- 
shohabati wata abhna wal ulamai aa'iliina wal mushan nifina mukhlisna wajami'i il wala malaaikati muqorrobina khusson Syeh Abdulqodir Jaelani rodialohu anhu syaillillaahi lahumul, dilanjutkan membaca Surat Alfatihah 1 kali. Kemudian, membaca "Tsuma ila arwahi arbanina waumahatina wa-ajwajina wazadatina walihajatina wa ihwanina wajami'il muslimi wal muslimat walmu'minin walmu'minat alahya minhum wal amwat wabil khususon Kanjeng bin Pangeran dilanjutkan membaca Surat Alfatihah (1 kali).

Setelah membaca doa-doa tersebut, kemudian dilanjutkan dengan membaca Bissmillahirrohmanirrohim 111 kali, surat Alfatihah 41 kali, Al-Ikhlas 101 kali, Sholawatnariyah 44 kali, dan terakhir, membaca doa berikut ini "Bismilahirrahmanirrahim, Wakur robi anjalni munjalam, mubarokaw waangta khoerul walhamdulillahirobil'alamin", sebanyak 41 kali.

Salah seorang responden lainnya, menyebutkan bahwa makam keramat di Parasean Gede Gunung Ciung merupakan tempat disemayamkan beberapa leluhur Sumedang di antaranya Pangeran Kornel, Pangeran Santri, Ratu Pucuk Umum, dan lain-lain. Keberadaan makam keramat tersebut, adalah sebagai bukti bahwa masyarakat Sumedang memiliki leluhur yang patut dijadikan suri tauladan, mereka telah berjasa terhadap masyarakat Sumedang, serta telah mengharumkan nama Sumedang. Oleh sebab itu, tuturnya para leluhur Sumedang patut dihormati dan dihargai serta diteladani dan ditiru semasa hidupnya. Sebagai bentuk penghormatan dan penghargaan dapat diwujudkan dengan cara berziarah dan mendoakan arwahnya, serta merawat atau memelihara kelestariannya agar generasinya dapat mengetahui keberadaannya serta tidak kehilangan jejak leluhur 'karuhun'.

Responden lainnya menyebutkan, makam keramat Pangeran Santri, dan Ratu Dewata Pucuk Umum (istri Pangeran Santri) merupakan makam leluhur Sumedang yang dianggap memiliki kharismatik. Seorang ulama besar (Pangeran Santri) yang menyebarkan ajaran Islam kepada masyarakat Sumedang. Responden mengatakan bahwa makam itu tempat untuk berziarah, tempat memohon sesuatu, terutama mendapat barokah yang berhubungan dengan kewibawaan, mendapatkan kedudukan dalam suatu jabatan dalam pemerintahan, dan sebagainya.

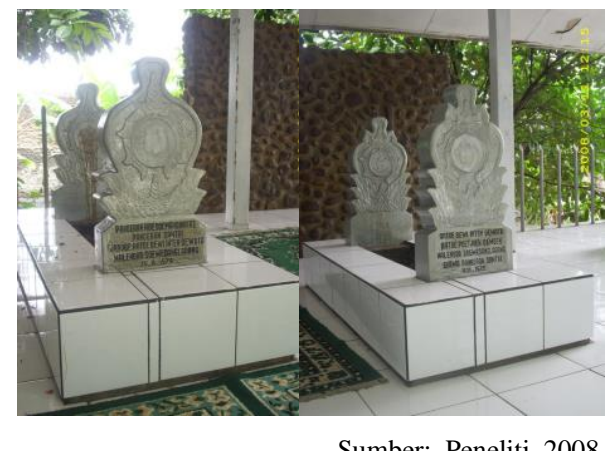

Sebelah kiri makam Pangeran Santri, dan kanan makam Ratu Pucuk Umum

Menurut persepsi responden (40 tahun) yang tinggal di sekitar komplek makam keramat, ia mengatakan tinggal di tempat itu sudah puluhan tahun. Ibu yang kegiatan sehari-harinya sebagai ibu rumah tangga mengatakan bahwa makam keramat itu merupakan salah satu kebanggaan bagi masyarakat Sumedang. Makam keramat itu perlu dipelihara, dilestarikan terutama untuk generasi muda, agar mereka mengenal dan belajar menghargai jasa leluhurnya. Makam keramat bukan sekedar makam, tetapi ada keistimewaannya bila dibandingkan dengan makam lainnya. Orang yang dimakamkan di komplek makam itu, 
adalah para karuhun atau menak Sumedang yang tidak disangsikan lagi kebaikannya, amal sholehnya, atau orang kekasih Allah dan sebagainya"

Persepsi lain dari masyarakat setempat ada yang menyatakan bahwa: "makam keramat yang sering dikunjungi oleh peziarah antara lain makam keramat Pangeran Santri, Ratu Pucuk Umum, dan Pangeran Kornel. Hal ini kemungkinan karena ketiga tokoh ini dianggap sebagai cikal bakal leluhur Sumedang yang legendaris dan tercatat di benak masyarakat Sumedang terutama makam keramat Pangeran Santri dan Ratu Dewata Pucuk Umum sebagai orang tua Pangeran Geusan Ulun yang pernah berjaya dimasa Kerajaan Sumedang Larang. Demikian pula tokoh Pangeran Kornel, mereka tahu siapa dia. Itulah sebabnya mengapa ketiga makam keramat tersebut lebih banyak dikenal masyarakat dari pada makam keramat lainnya."

Menurutnya, setiap makam keramat memiliki perbawa masingmasing, dan berhasil tidaknya maksud peziarah bergantung pada keyakinanya. Tentang perbawaan makam keramat, Bapak Kuncen menyebutkan bahwa setiap makam keramat memiliki perbawa berkah masing-masing. Ada perbawa keberuntungan pada bidang kesuksesan dalam usaha, perdagangan, jodoh, keselamatan, kewibawaan, kepemimpinan (kedudukan dalam pemerintah), dan lain lain. Waktu dan maksud peziarah berziah ke makam keramat pun bebas-bebas saja, dalam artian kapan saja, tidak mengikat masalah waktu, yang jelas peziarah mendoakan para leluhur dengan harapan mendapat berkah dari Tuhan Yang Maha Kuasa sesuai dengan keinginan masing-masing. Hari yang baik untuk berziarah biasanya hari Selasa (malam Selasa), atau Jumat (malam Jumat Kliwon). Di tempat makam keramat, peziarah pun ada yang melakukan sholat, berzikir bahkan tidurtiduran atau pun bermalam.

\section{Persepsi Masyarakat Peziarah}

Para peziarah berpendapat bahwa makam-makam yang dikeramatkan itu merupakan makam leluhur Sumedang yang digolongkan kepada waliyullah. Oleh kerena itu pada hari hari tertentu, seperti pada malam Jumat kliwon para peziarah yang datang lebih banyak dari hari-hari biasa.

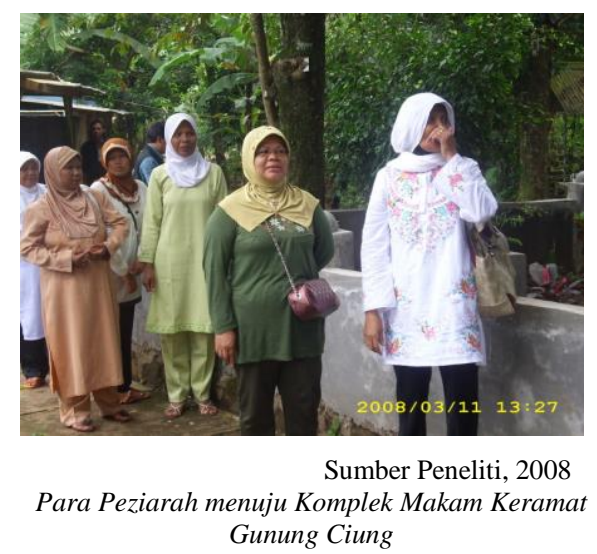

Selain itu, tokoh-tokoh yang dikeramatkan ini diyakini bahwa mereka digolongkan sebagai orang-orang yang berjasa yang memiliki berbagai kelebihan dan kemampuan yang dapat memajukan kehidupan masyarakat, baik moril maupun materil. Adapun bentuk nyata jasa tersebut, antara lain mereka mampu mengukir sejarah perjalanan kehidupan masyarakat Sumedang, hingga dikenal sebagai masyarakat yang agamis (Islam).

Setiap orang yang berziarah ke makam keramat dalam dirinya diperkuat dengan emosi keagamaan. Dengan emosi keagamaan itu mereka berusaha memusatkan dirinya pada alam sakral untuk memohon kepada Allah SWT di tempat yang diyakini sebagai seorang kekasih Allah, sehingga dia berharap ada barokah (berkah) yang kembali kepada 
dirinya dan dapat terkabul segala permohonan atau dapat tercapai segala hal yang menjadi tujuannya datang ke tempat itu.

Para peziarah yang datang itu satu sama lain masing-masing mempunyai persepsi yang tidak sama, tergantung dari tujuan mereka dan kebutuhan mereka datang ke makam itu, sehingga persepsi para peziarah tentang makam itu bervariasi.

Persepsi yang menyebutkan makam keramat merupakan tempat yang dapat memberikan arti. Arti bagi peziarah karena keyakinan ia dapat menemukan suatu yang diharapkannya. Salah seorang informan menyebutkan bahwa makam keramat ini memiliki arti, ia sering datang ke tempat ini, ia selalu mendapatkan apa yang menjadi harapannya. Bagi peziarah lainnya, pandangan atau persepsi makam keramat ini sebagai tempat untuk meminta sesuatu. Orang yang menginginkan sesuatu berkenaan dengan kebutuhan hidupnya dapat menanjatkan permintaan yang dipanjatkan kepada Tuhan Yang Maha Kuasa di tempat ini. Persepsi berikut tentang makam Gunung Ciung ini adalah persepsi yang menyebutkan bahwa makam Gunung Ciung adalah tempat yang bisa memberi keselamatan jasmani dan rohani. Persepsi peziarah yang lainnya yaitu bahwa makam Gunung Ciung ini merupakan makam keramat (sakral). Persepsi ini disebut diungkapkan oleh seorang peziarah. Ia mengatakan bahwa maksud datang ke makam ini adalah untuk meresihan awak) (membersihkan diri). Menurut pandangannya, makam keramat ini tempat yang cocok. Rencananya, ia akan berziarah juga ke makam Prabu Geusan Ulun.

Persepsi berikutnya yang mengatakan bahwa makam keramat ini sebagai tempat untuk tafakur, bermunazat, dan perilaku spiritual lainnya. Persepsi ini secara singkat merupakan tempat yang cocok bagi para peziarah yang lebih mengutamakan kehidupan spiritual. Persepsi ini seperti disebutkan oleh peziarah dari Cisalak, Subang. Menurut pengakuannya ia sudah pernah berziarah ke makam para wali di Jawa Tengah dan Jawa Timur.

Menurut penilaian (dari berbagai pengalamannya berziarah selama ini) kepada para peziarah lainnya baik yang berziarah di makam keramat ini maupun ke tempat ziarah lainnya, yang perlu diperhatikan adalah bekal ilmu. Menurutnya tidaklah tepat jika datang ke tempat ini sambil meminta sesuatu dan diucapkan di depan makam. Sebaiknya di makam yang anggapannya adalah makam orang shaleh adalah mendoakan kepada ahli kubur agar jasa-jasanya mendapat ganjaran yang berlipat oleh Allah SWT. Sebaiknya doa yang disampaikan setelah shalat malam dan shalat wajib. Dari perilaku ibadah (spiritual) ini nantinya akan ada berkah yang kembali (mamantul) kepada kita. Dengan kata lain makam ini tempat yang cocok untuk ngalap berkah, dari Pangeran Santri dan para pengiringnya yang tergolong orang yang shaleh.

Pada umumnya persepsi ini (mengutamakan kehidupan spiritual) banyak disebutkan oleh para peziarah yang sudah lanjut usia, atau mereka yang tidak lagi banyak berpikir tentang masalah-masalah yang berhubungan dengan kehidupan duniawi. Dari kenyataan di lapangan, banyak peziarah yang datang pada malam hari, kebanyakan setelah jam 21.00 bahkan ada yang datang tengah malam. Umumnya peziarah seperti ini tidak minta di antar oleh juru kunci. Mereka langsung datang dan melapor kepada petugas piket serta memohon ijin untuk masuk ke komplek makam keramat Gunung Ciung. Di makam mereka melakukan tafakur, mengamalkan wirid, dan sebagainya 
hingga waktu subuh dan pagi-pagi peziarah ini pulang.

Demikian persepsi atau pandangan para peziarah tentang makam keramat leluhur Sumedang ini. Berbagai pandangan para peziarah yang datang disebabkan oleh berbagai kepentingan serta motivasi ini. Dari pemantauan di lapangan, persepsi yang paling banyak diungkapkan oleh para peziarah bahwa makam Pangeran Santri merupakan tempat meminta sesuatu, tempat yang bisa memberikan harapan hidup lebih baik, tempat yang bisa memberikan keselamatan jasmani dan rohani. Selanjutnya banyak pula para peziarah yang berpandangan bahwa makam Pangeran Santri sebagai tempat yang sakral.

Tentunya, persepsi atau situasi batin para peziarah terhadap makam keramat di Gunung Ciung adalah sepenuhnya hak dari para peziarah sendiri. Walaupun para juru kunci selalu menekankan kepada para peziarah melalui mukadimah sebelum acara tawasulan dimulai. Penekanan atau pelurusan kembali anggapan bahwa tempat ini (makam) yang akan memberikan sesuatu yang diharapkan para peziarah adalah keliru. Yang harus diingat bahwa di tempat ini dimakamkan seseorang yang diyakini sebagai kekasih Allah SWT, waliyullah, atau orang shaleh. Apa yang menyebabkan para peziarah datang dari tempat-tempat yang jauh ke tempat ini. Tentunya perbuatan, amal shaleh yang telah dilakukan oleh orang yang dimakamkan di tempat ini yang menjadikan sebab tempat ini menjadi tujuan wisata ziarah. Sebagai landasan yang perlu diperhatikan dari ziarah ini, menurut sesepuh juru kunci makam, adalah tadzkiratul maut, atau mengingat akan mati. Sudahkah kita mempersiapkan segala sesuatu untuk bekal mati; demikian mukadimah atau penjelasan pendahuluan yang selalu disampaikan setiap sebelum acara tawasulan di mulai.

Persepsi yang dikemukakan oleh responden lain mengatakan bahwa mendoakan yang sudah tiada (meninggal) merupakan perbuatan yang baik. Demikian pula mendoakan para leluhur Sumedang. Dengan cara demikian semoga Allah SWT memberi berkah kepada yang didoakan dan kepada yang mendoakannya. Atas berkah-Nya, semoga apa yang diinginkan dalam kehidupannya dikabulkan, diberi kelancaran dalam berbagai hal. Menurut responden ini, ia sering berziarah ke makam keramat leluhur Sumedang baik bersama keluarga maupun rekan kerjanya. Maksudnya dengan mendoakan semoga diberi kemudahan dalam usahanya. Seperti halnya peziarah lainnya, bila selesai berziarah ke makam keramat leluhur Sumedang, kemudian meminta "Air Barokah". Menurut peziarah, dengan perantara air doa tersebut, mudahmudahan mendapat berkah dari Allah SWT dan diberi kemudahan dan kelancaran dalam menjalankan usaha. Seperti biasa dilakukan perziarah, setelah ia berdoa di makam leluhur Sumedang, kemudian air doa atau 'air barokah' itu dipakai mandi, dan sebagian minum.

Kehidupan beragama masyarakat Sumedang sejak lama terdengar terutama ketika kekuasaan Pangeran Santri yang menikah dengan Ratu Pucuk Umum. Mereka memiliki misi yang sama yaitu menyebarkan ajaran agama (Islam), khususnya di wilayah kekuasan kerajaan Sumedang Larang, dan umumnya di Jawa Barat.

Pengaruh dan nilai-nilai keagamaan (Islam) yang mereka tanamkan kepada masyarakat tentunya sangat berpengaruh besar pada kelangsungan kehidupan masyarakat, sehingga menjadi masyarakat yang agamis. Itu bukan hanya kalangan 
tua yang melaksanakan aqidah-aqidah ke-Islaman tersebut, anak-anak muda sejak dini diperkenalkan pada nilai-nilai ke-Islaman. Sehingga ada penerusnya, dan yang tercatat antara lain salah satunya Kyai Mas Haji Sanusi sebagai ulama Sumedang yang wafat dan dimakamkan di makam keramat Gunung Puyuh. Untuk mengungkapkan rasa terimakasih dan penghormatan atas jasa leluhurnya, mereka tuangkan ke dalam bentuk dan cara yang khusu yang salah satunya dengan berziarah, dan mendoakannya.

Berziarah berarti mengunjungi atau mendatangi makam untuk mendoakan. Berziarah dianjurkan oleh Rasullulah Saw, tetapi sebatas untuk mengingatkan kepada manusia sebagai makhluk hidup yang bernyawa akan mengalami mati. Kematian merupakan rahasia Allah SWT, siapa pun tidak dapat mengetahuinya kapan seseorang akan dipanggil oleh Allah SWT. Oleh karena kita harus mempersiapkan bekal untuk di akherat nanti. Bagi yang sholeh dan beramal baik, selalu dikenang dan dijadikan teladan, sehingga tidak sedikit orang yang berkunjung ke makam tersebut untuk mendoakan agar amal ibadah bersangkutan diterima oleh Allah SWT, ditempatkan disisi-Nya, dan sebagainya. Makam yang dikunjungi adalah makam yang dianggap orang suci (seorang wali), seorang ajengan atau Kyai dalam bidang Tariqat. Adapun seorang tokoh yang tekun dan menyebarkan ajaran agama Islam serta dimitoskan oleh masyarakat yang percaya dan meyakininya sebagai penuntun hidup, yakni tokoh leluhur Sumedang, antara lain Pangeran Santri, Ratu Pucuk Umum, Pangeran Kornel dan seterusnya.

Nilai yang dapat dipetik dari kegiatan budaya spiritual ke makam keramat tersebut antara lain adalah nilai religius. Nilai religius adalah untuk menyadarkan manusia bahwa hidup di dunia itu tidak abadi, melainkan mau tidak mau penghuni alam semesta ini akan mengalami binasa (mati). Sebagaimana para leluhur mereka yang telah dimakamkan di tempat tersebut. Selain itu, kesadaran akan adanya kekuatan kodrati di atas kekuatan manusia, yakni kekuatan Tuhan Yang Maha Kuasa. Dalam hal ini, memohon berkah kepada para leluhur mereka agar permohonannya bisa dikabulkan oleh Tuhan Yang Maha Kuasa. Mereka beranggapan bahwa para leluhur, adalah tokoh orang suci yang relatif dekat dengan Tuhan sehingga kalau suatu permohonan disampaikan melalui perantara beliau diharapkan Tuhan berkenan mengabulkannya. Kegiatan spiritual di makam keramat tersebut juga dapat dimaknai sebagai lambang penghormatan masyarakat kepada para leluhurnya dan pendahulunya yang telah banyak berjasa dalam kehidupan mereka.

Nilai religius yang dapat dipetik dari berziarah, secara garis besarnya manusia hanya bisa berusaha, yang menentukan hanyalah Allah SWT. Keyakinan atas kekuasaan-Nya, kebesaranNya, dan kasih sayang-Nya maka bila Allah SWT menghendaki tidak ada yang tidak mungkin terjadi. Bagi-Nya kecil untuk mengubah kehidupan manusia. Oleh karena itu, bila berziarah hendaknya berdasarkan ajaran (Islam) yang dianjurkan oleh Nabi Muhammad Saw. Itulah tatacara berziarah ke makam yang dianjurkan oleh Rosullulah kepada umatnya. Berziarah dianjurkan dan sunat hukumnya. Itu setelah keadaan berubah di mana umat Islam sudah kuat memegang Aqidah. Adapun larangan apabila berziarah ke makam tidak boleh menginjak atau menduduki kuburan, apalagi dibagian kepalanya. Seseorang yang sudah meninggal tidak boleh dibicarakan kejelekannya. 
Peziarah mendoakan akhli kubur memang sewajarnya, bukan sebaliknya peziarah mohon bantuan sesuatu kepada akhli kubur. Ada dua pendapat dalam hal berziarah/mengunjungi atau mendoakan akhli kubur. Pertama, untuk mendoakan akhli kubur tidak selalu harus diucapkan di depan kuburan orang tersebut. Alasannya, doa itu bukan tali, walaupun disampaikan dari rumah, masjid, dan sebagainya tentu akan sampai kepada Tuhan. Kedua, memang doa itu bukan tali tetapi ada tempat utama dan ada pula tempat yang lebih utama. Doa yang disampaikan dari rumah itu pun baik, tapi lebih utama jika secara langsung diucapkan di depan makam orang yang dimaksud. Di depan makam setidaknya akan membantu hati lebih khusuk dalam memanjatkan doa.

Secara tidak disadari kegiatan peziarah dapat saja tergelincir kepada praktek syirik (menyekutukan Allah SWT) yang bertentangan dengan aqidah Islam. Untuk mencegah, menghindari dan menanggulangi hal tersebut, perlu adanya pembinaan atau pengarahan dari pemuka agama (ustadz) secara perlahanlahan.

Sebenarnya bergantung pada motivasi itu sendiri, bila sebatas ingin mendoakan akhli kubur agar diberikan berkah dan diampuni dosanya oleh Allah Swt mungkin tidak tergolong menyekutukan Allah SWT. Tapi bila motivasinya ngalap berkah (mencari berkah) atau mohon bantuan sesuatu yang dari sudah meninggal, tentu masalahnya menjadi lain. Jangankan untuk mengurusi atau membantu orang lain (yang masih hidup), untuk mempertanggungjawabkan diri sendiri pun repot. Jadi sudah sewajarnya, orang yang masih hidup mendoakan kepada orang yang sudah meninggal. Membaca ayat-ayat suci AlQuran atau doakan orang yang sudah meninggal dunia termasuk pula ibadah.
Bagi siapa saja yang membacakan ayatayat suci tersebut tentu mendapat pahala dan berkah dari Allah SWT. Oleh karena itu, bergantung dari sudut mana kita memandang segala sesuatu itu. Tidak dapat kita pungkiri, bahwa ada kesalahpahaman dalam memandang tetang ziarah itu. Kesalahpahaman itu semakin lama semakin merebak sehingga sulit dibedakan, mana yang dianjurkan dan mana yang dilarang.

Terlepas dari itu semua, ziarah itu sudah merupakan kebiasaan atau tradisi masyarakat yang sulit ditinggalkan meski ada kontroversi dari segi keimanan. Walaupun demikian, selama kegiatan itu tidak menyesatkan dan tidak ke luar dari rambu atau aturan-aturan yang ada tidak menjadi masalah. Selain itu, selama masih memiliki nilai budaya yang dapat bermanfaat bagi kehidupan masyarakat pendukungnya. Tetapi tentu ada hikmah yang dapat kita petik dari berziarah, antara lain turut mendoakan kepada yang diziarahi (akhli kubur) agar mendapat Maghfirah (ampunan) dari Allah SWT dan mendapatkan rahmat, pahala dan mengingatkan kepada kita akan alam akherat, mengingatkan kita untuk dapat berzuhud terhadap alam, dan mengambil suri tauladan

Mengingatkan akan alam akhirat, bahwa kelak di alam akhirat manusia yang telah mati akan dihidupkan kembali oleh Allah SWT untuk menerima keadilan balasan-Nya atas segala perbuatannya semasa ia hidup di dunia ini. Bila berbuat kebaikan atau beramal shaleh akan dibalas dengan pahala, sebaliknya bila berbuat jelek akan dibalas dengan siksa neraka. Oleh karena itu, sebelum ajal menjemput, segeralah bertaubat kepada Allah SWT dengan memohon ampunan atas segala kesalahan yang telah kita perbuat.

Dengan berziarah, dapat mengingatkan bahwa kita pun akan 
mengalami kematian seperti itu, hanya saja tinggal menunggu waktu. Tentang waktu, itu rahasia Allah SWT dan hanya Allah SWT Yang Maha Mengetahui segalanya. Manakala ajal menjemputnya, putuslah segalanya kecuali amal ibadahnya yang akan menolong dan anak sholeh yang mendoakannya serta ilmunya yang bermanfaat. Di dalam kubur tidak ada seorang pun yang akan sanggup menemani dan menolong, kecuali amal kebajikan. Begitu pun harta benda yang dimiliki tidak akan menolong, bahkan justru sebaliknya memberatkan, kecuali harta benda itu diamalkan sesuai perintah Allah SWT. Oleh karena itu, janganlah terpikat dengan tipu daya keduniawian. Janganlah diperbudak oleh harta, karena dengan berlimpahnya justru akan mencelekakan di dunia maupun di akhirat, kecuali diamalkan sesuai perintah Allah SWT tentu akan membawa keberuntungan.

Dengan berziarah ke makam keramat para wali, ulama atau yang dianggap sebagai syuhada (pahlawan) termasuk para leluhur yang telah berjasa kepada masyarakatnya, maka dapat diambil ketelaudananmya. Sebagai rasa hormat dan ucapan terima kasih atas jasajasanya, maka sepatutnya selalu mendoakan kepada ahli kubur agar mereka diberi tempat yang terang, dihapuskan dosanya, dan selalu dikasihi oleh Allah SWT. Dengan berziarah, diharapkan ketauladan ahli kubur semasa hidupnya dicontoh oleh generasi berikutnya.

Berziarah atau mengunjungi makam keramat merupakan suatu upaya untuk mendoakan yang diziarahi dan mencari berkah dari Allah SWT, tetapi bagi yang memiliki motivasi lain, yakni hendak memohon pertolongan kepada yang diziarahi, maka kegiatan itu bertentangan dengan ajaran Islam, karena termasuk menyekutukan Tuhan. Perbuatan tersebut disebut musyrik, dan hukumnya dosa besar.

Peziarah hendaknya pandai memilah-milah, jangan sampai terjerumus dan menjadi umat yang rugi. Bagi yang belum dapat memahami, bila dirasakan besar manfaatnya maupun sebaliknya itu merupakan suatu resiko yang harus diterimanya. Namun atas keyakinan, mereka siap melakukan apa saja walaupun memerlukan pengorbanan moril maupun materil. Secara materi misalnya, tidak sedikit jumlah biaya yang harus dikeluarkan, walaupun maksud dan tujuan yang diinginkan belum tentu terkabul. Rupanya masalah itu tidak menjadi dilema, karena menyadari bahwa segala suatu itu perlu upaya, walaupun yang menentukan segalanya hanya Allah SWT. Tidak dapat dipungkiri, itulah salahsatu sistem kepercayaan yang ada dan berkembang di masyarakat kita. Namun itu merupakan nilai budaya bangsa yang sarat dengan nilai luhur.

Berdasarkan wawancara dengan para penziarah, jelaslah bahwa alasanalasan yang melatarbelakangi orang berkunjung ke makam keramat tersebut adalah:

- Adanya sunnah nabi yang mengatakan pahala bagi orang-orang yang berziarah ke makam leluhur, orang tua, dan para wali yang menyebarkan agama Islam. Pengertian pahala dalam konteks ini tentu sangat luas, bukan hanya berupa kondisi kejiwaan (hati menjadi tenang, tenteram) juga adanya suatu keyakinan terpelihara-nya hubungan batin dengan si mati, dan pahala dalam pengertian wujud konkrit seperti keselamatan hidup, kemudahan mencari rezeki, dan sebagainya.

- Adanya getaran emosi keagamaan yang menuntun manusia melakukan kegiatan religius. Banyak cara yang 
dilakukan ketika berziarah ke makam keramat seperti melakukan tahlilan di dalam bangunan makam keramat Pangeran Santri dan Ratu Pucuk Umum, atau dibangunan makam keramat Pangeran Kornel.

- Adanya berbagai motivasi peziarah antar lain sengaja berkunjung ke makam keramat ini untuk melakukan tawasul dalam pengertian, memohon kepada Allah SWT atas berbagai keinginan atau niat, seperti permohonan dibukakan pintu rizki, dimudahkan dalam usahanya, disegerakan mendapat kenaikan pangkat, memperoleh kedudukan, disegerakan mendapatkan pasangan hidup yang baik, dan diberi keturunan yang baik (sholeh). Pada umumnya para peziarah datang berkunjung ke makam keramat tersebut dilandasi dengan niat dan tujuan yang didorong oleh kemauan batin yang mantap. Adanya niat dan tujuan tersebut membuat motivasi peziarah berjadi beragam. Niat dan tujuan yang itu juga dipengaruhi oleh informasi yang didapat. Kebanyakan peziarah mendengar dan mengetahui karena diberitahu oleh temannya, atau kerabatnya atau tetangganya tentang 'kekeramatan atau kharisma" makam keramat tersebut yang dianggap dapat memberi harapan untuk hidup lebih baik dibanding sekarang, memberi keselamatan, ketenangan hidup, dan lain sebagainya. Niat mereka untuk berziarah itu ada yang karena memang kemauan sendiri, tetapi ada juga yang karena diajak atau dianjurkan oleh teman, tetangga, atau kerabatnya, terutama oleh yang merasa berhasil mencapai keinginannya setelah berziarah kemakam keramat tersebut. Oleh karena itu, cara berkunjungnya juga ada yang seorang diri, diajak atau mengajak teman/saudara, maupun secara rombongan. Mengenai frekuensi kunjungan, terdapat peziarah pemula (baru pertama kali berkunjung), dan ada juga yang sudah beberapa kali, bahkan yang rutin setiap minggu. Pada umumnya, menurut mereka, apa yang mereka "minta" atau "harapkan" itu terbukti. Hal inilah yang membuat masyarakat mempunyai persepsi bahwa makam keramat itu adalah tempat untuk mencari berkah, tempat untuk "mengubah nasib", dan sebagainya. Ada persepsi kemudian memotivasi peziarah yang datang untuk mencari berkah tersebut adalah kenyataan yang ada dalam hati para peziarah. Persepsi yang diwujudkan dengan kenyataan peziarah inilah yang antara lain membuat makam keramat tersebut menjadi tempat untuk "meminta".

\section{Penutup}

Walaupun diterpa gelombang arus globalisasi, ternyata masyarakat kita masih ada yang berpegang teguh pada kepercayaan adat istiadat leluhurnya. Kepercayaan sebagai keyakinan dalam hidupnya diwujudkan di antaranya dengan tindakan berkunjung ke tempat yang dianggap suci atau keramat. Tempat-tempat semacam ini dianggap memiliki kekuatan gaib dan mistik. Di kabupaten Sumedang, terdapat makam keramat leluhur Sumedang. Mereka sangat hormati karena berjasa semasa hidupnya. Selain itu mereka dianggap memiliki nilai karismatik dan religius bahkan dianggap sebagai orang suci yang dianggap mendatangkan karomah. Oleh karena itu makam keramat tersebut banyak diziarahi baik oleh masyarakat sekitar maupun dari luar daerah Kabupaten Sumedang. Peziarah berkunjung ke makam keramat tersebut dilandasi beberapa persepsi antara lain:

- Makam keramat leluhur Sumedang merupakan tempat yang mempunyai arti yang dapat memberi sesuatu yang 
dicari oleh peziarah, dan merupakan tempat yang dapat memberikan harapan hidup yang lebih baik

- Peziarah berkeyakinan bahwa makam keramat Leluhur Sumedang adalah tempat untuk mencari keselamatan jasmani maupun rohani

- Makam keramat Leluhur Sumedang, (makam Pangeran Santri, Ratu Pucuk Umum, dan Pangeran Kornel) merupakan salah satu tempat yang sakral.

- Peziarah berkeyakinan bahwa tempat makam keramat terebut merupakan tempat untuk melakukan tafakur, atau tempat yang tepat bagi peziarah yang mengutamakan kehidupan spiritual.

Adanya persepsi peziarah terhadap makam ini, mendorong peziarah berkunjung dengan berbekal niat atau motivasi tersendiri. Persepsi terhadap makam ini menyebabkan peziarah memiliki motivasi tertentu untuk berkunjung melaksanakan niatnya. Adanya persepsi yang melandasi peziarah terhadap makam keramat, dari sisi spiritual menandakan bahwa manusia dalam melaksanakan upayanya tidak hanya bermodal kepada upaya jasmani, namun upaya batiniyah menunjukkan bahwa manusia tidak berdaya dalam memenuhi kebutuhannya. Untuk itu, manusia mencari hubungan dengan kekuatan Tuhan Yang Maha Kuasa dalam memenuhi kebutuhan tersebut.

\section{Saran}

Perlu adanya pengelolaan yang lebih proposional, agar layak dijadikan wahana wisata budaya bagi masyakat di Jawa Barat. Selain itu agar pada waktu melakukan ziarah tetap memperhatikan tatacara ziarah yang mengacu pada aqidah-aqidah agama Islam. Namun demikian, kita perlu menyadari bahwa peziarah itu adalah mereka yang dalam tingkah laku atau tindakannya telah berpola oleh sistem nilai budaya yang didukungnya serta bersumber pada agama lokal atau kepercayaan.

\section{DAFTAR PUSTAKA}

AM, Imron. 1990.

Kitab Manakib Syekh Abdul Qadir Jaelani. Bangil: Yayasan AlMuslimin.

Baal, van J. 1987.

Sejarah dan Pertumbuhan Teori Antropologi Budaya. Jakarta, Gramedia.

Boedi, Oerif Bramantyo. 2007.

"Kutamaya:Peran pada Masa Kerajaan Sumedang Larang dan Sebagai Situs Arkeolog"i, dalam: Bhakta Astiti, Depbudpar. Bandung: Ikatan Arkeologi Indonesia.

Dhofier, Zamakhsyari. 1990.

Tradisi Pesantren, Studi tentang Padangan Hidup Kyai. Jakarta: LP3ES.

Geertz, Clifford. 1992.

Kebudayaan dan Agama. Yogyakarta: Kanisius.

Koentjaraningrat. 1990.

Kebudayaan, Mentalitas dan Pembangunan. Jakarta: Gramedia Pustaka Utama. 1992.

Beberapa Pokok Antropologi Sosia. Jakarta: Dian Rakyat.

Lubis, Nina H. 2000.

Tradisi \& Transformasi Sejarah Sunda I. Bandung: Humaniora Utama Press.

Nasution, Harun, et.al. 1990.

Toriqot Qodiriyyah Naqsabandiyyah: Sejarah Asal-Usul, dan Per- 
kembangannya. Bandung: Remaja Rosdakarya.

Rahardjo, Supratikno (ed.). 2005.

Religi Dalam Dinamika Masyarakat. Bandung: Ikatan Ahli Arkeologi Indonesia (IAAI).

Rasyidi, HM., Harifudin Cawidu. 1984 Islam untuk Disiplin Ilmu Filsafat, Jakarta: Kuning Mas.

Subagya, Rachmat. 1981.

Agama Asli Indonesia. Jakarta: Sinar Harapan dan Yayasan Cipta Loka Caraka.

Sucipto, Toto. 2005.

Budaya Spiritual di Lingkungan Makam Keramat Wangsa Goparana Sagalaherang, dalam :Budaya Spiritual Masyarakat Sunda, Depbudpar, Balai Kajian
Sejarah dan Nilai Tradisional Bandung. Jatinangor: Alqaprint.

Suhadi, Machdi \& Halina Hambali. 1994/1995.

Makam-Makam Wali Sanga di Jawa. Jakarta: Depdikbud.

Suseno, Frans Magnis. 1993.

Etika Jawa. Jakarta: Gramedia Pustaka Utama.

Susanto, Harry, P.S. 1987.

Mitos, Menurut Pemikiran

Mircea Eliade. Yogyakarta:

Kanisius,

Tasadi, et.al. 1994-1995.

Budaya Spiritual dalam Situs Keramat di Gunung Kawi Jawa Timur. Jakarta: Depdikbud. 